\title{
Information Resources Management
}

The Information Resources Management (IRM) Team, in the Geographic Information Office (GIO) of the U.S. Geological Survey (USGS), manages compliance with information mandates defined by Public Law, the Office of Management and Budget (OMB) (specifically Circular A130), the National Archives and Records Administration, the Department of the Interior (DOI), and other official sources. The team uses a variety of mechanisms to fulfill USGS IRM requirements from coordination through USGS-wide teams, to topical training sessions, to one-on-one communications with individual USGS programs. In addition, the team serves as a bureau contact for Federal Register notices and as the group contact for USGS Federal Advisory Committees. Currently, an IRM employee-awareness training course is being developed, in coordination with the DOI, that will provide an overview of IRM requirements. Below is a list of some of the Federal mandates for which the IRM team ensures USGS compliance.

\section{Federal Records Act}

For more than 50 years, the Federal Records Act has required agencies to create and maintain adequate documentation of their record-keeping policies and official business transactions. Complete and accurate scientific and administrative records are essential components documenting the value of the USGS. The DOI is currently investigating and drafting a strategy for future implementation of electronic records management to address $\mathrm{OMB}$ requirements.

\section{Privacy Act}

The purpose of the Privacy Act is to balance the government's need to maintain information about individuals with the rights of individuals to be protected against unwarranted invasions of their privacy stemming from Federal agencies's collection, maintenance, use, and disclosure of personal information about them. The Privacy Act is also concerned with potential abuses presented by the government's increasing use of computers to store and retrieve personal data by means of a universal identifier--such as an individual's social security number.

\section{E-Government Act of 2002}

The E-Government Act of 2002 requires agencies to conduct privacy impact assessments for electronic information systems and collections and make them publicly available, post privacy policies on agency websites used by the public, translate privacy policies into a standardized machine-readable format, and report annually to OMB on compliance with Section 208 of this Act.

\section{Rehabilitation Act, Section 508}

The Rehabilitation Act of 1973, Amendments of 1998, Section 508, requires that electronic and information technology developed, procured, maintained, or used by the Federal Government be accessible to people with disabilities in a comparable manner that it is to those who do not have disabilities. The binding enforceable provisions of this Act are the procurement regulations and technical standards that constitute what is accessible technology.

\section{Freedom of Information Act}

The Freedom of Information Act (FOIA) is based on the principle of openness in government and generally provides that any person has a right, enforceable in court, of access to Federal agency records, except to the extent that such records are protected from disclosure by one of nine exemptions or by one of three special law enforcement record exclusions. A FOIA request for a copy of USGS records can be made by any individual or public or private organization other than a Federal agency.

\section{Clinger-Cohen Act and the Federal Acquisitions Reform Act}

These Acts require Federal Government agencies to establish policies and procedures for reviewing, approving, and processing information technology investments. In all acquisitions, USGS follows DOI guidelines in complying with these regulations.

\section{Paperwork Reduction Act}

To minimize the paperwork burden imposed on the public, Federal agencies are required to obtain OMB approval for information collections. Generally an "information collection" means the obtaining or soliciting of information by an agency from 10 or more persons by means of identical questions. 
Treasury and General Government Appropriations Act for FY01, Section 515, Information Quality

Congress directed the OMB to issue Federal Government-wide guidelines that "provide policy and procedural guidance to Federal agencies for ensuring and maximizing the quality, objectivity, utility, and integrity of information (including statistical information) disseminated by Federal agencies." OMB's guidelines were published in the Federal Register on February 22, 2002.

\section{IRM Staff}

Joye Durant

Frank Andreani

Amy Berger

John Cordyack
Acting Chief

Clinger-Cohen Act; Federal Acquisitions Reform Act

Rehabilitation Act, Section 508

Freedom of Information Act; Paperwork Reduction Act
Nancy Faries

John Faundeen

Debbie Kimball

Colene Laignel

Marti Quigley

Carol Wippich

Reference: IRM Internal web site:

http://internal.usgs.gov/gio/irm/
Government Appropriations Act for FY01; Section 515

Federal Records Act (on detail)

Privacy Act, E-Government Act of 2002

Clinger-Cohen Act; Federal Acquisitions Reform Act

Systems Development Life Cycle; Privacy Act

Federal Records Act 